University of Wollongong

Research Online

Faculty of Social Sciences - Papers (Archive) Faculty of Arts, Social Sciences \& Humanities

$1-1-2016$

Metatalk: Enabling metalinguistic discussion about writing

Ruth Newman

University of Exeter

Debra Myhill

University of Wollongong, University of Exeter, d.a.myhill@ex.ac.uk

Follow this and additional works at: https://ro.uow.edu.au/sspapers

Part of the Education Commons, and the Social and Behavioral Sciences Commons

Research Online is the open access institutional repository for the University of Wollongong. For further information contact the UOW Library: research-pubs@uow.edu.au 


\title{
Metatalk: Enabling metalinguistic discussion about writing
}

\begin{abstract}
Historically, theoretical consideration of metalinguistic understanding has scarcely addressed the issue in the context of writing, other than in relation to early years writing development where there is a substantial body of work. Consequently, there is very limited understanding of how older writers in the upper primary and secondary phase of schooling develop metalinguistic understanding about writing. Arguably, writing is always an act of selecting, shaping, reflecting and revising (Myhill, 2011) and thus draws crucially on metalinguistic activity. Critical to the development of this metalinguistic understanding is how teachers manage $i$ metatalk $k_{i}$, talk about language use in writing, during instructional interactions around writing and how teachers enable developing writers to explore their thinking about how language shapes meaning in written text. This paper, drawing on data from a large national study, will explore the nature and efficacy of teachers $i$ interactions with students and how they enable high-level metatalk to occur, specifically how they create dialogic spaces for investigating meaning-making in written text. The paper will explore the close relationship between high-quality metatalk and open dialogic discourse roles for the teacher, but it will also highlight the complexity of metatalk for writing and how dialogic-monologic discourses are best viewed as a continuum which take account of other influencing factors.

\section{Disciplines}

Education | Social and Behavioral Sciences

Publication Details

Newman, R. \& Myhill, D. (2016). Metatalk: Enabling metalinguistic discussion about writing. International Journal of Educational Research, 80 177-187.
\end{abstract}




\section{METATALK: ENABLING METALINGUISTIC DISCUSSION \\ International Journal of Research in Education \\ Debra Myhill - University of Exeter \\ Ruth Newman - University of Exeter}

\section{Introduction}

Typically, many skills that we master become easier as our mastery increases, in terms of both physical and cognitive skills - for example, riding a bike, doing long division, or decoding phonemes into words. However, writing is atypical in that the demands of writing increase as writers' mastery of writing grows. Whilst the more basic skills of handwriting and spelling do indeed become easier with maturity, 'as writers mature and gain expertise, they invest more effort and reflective thought in the task' (Kellogg 1994: 204). As our capacity to create text on the page develops, so too does our expectations of what that text can achieve. These increased cognitive and social demands on developing writers require, amongst other things, increasing metalinguistic understanding about writing to inform the choices they make in composing written text. Yet, theoretical consideration of metalinguistic understanding has scarcely addressed the issue in the context of writing, other than in relation to early years writing development where there is a substantial body of work. Consequently, there is very limited understanding of how older develop metalinguistic understanding about writing. Unlike oral development which occurs naturally through social interaction, writing is a learned process, and has to be taught: thus a particular instructional issue is the role of the teacher in supporting the development of metalinguistic understanding. Critical to the development of this metalinguistic understanding is how teachers manage 'metatalk', talk about language in writing, during instructional interactions around writing. This paper reports on data from a study investigating a pedagogical intervention linking the teaching of writing with the teaching of grammar, in which teacher facilitation of high-quality talk about language choices was a key pedagogical principle. The paper will reveal how teachers' management of discussion about metalinguistic choices in writing frames students' capacity to think metalinguistically about their writing, and will argue that constructive metatalk in writing occurs in dialogic spaces created by the teachers' adoption of open dialogic discourse roles.

\section{Theoretical Framework:}

Our view of the central role of metalinguistic understanding in writing is underpinned by a social cultural view of grammar represented by Hallidayian functional linguistics. This framework adopts a meaning-oriented theorisation of grammar, concerned to explore the relationship between text and context, and looking not simply at lexical or syntactical aspects of grammar but also the discourse elements of organisation, development and cohesion (Halliday 1994). It regards language as fundamentally a social semiotic system, as 'abstract semiosis' (Halliday 2004:5): the concern is with understanding how language works to make meaning. Halliday argues that any act of communication requires the making of choices and that 'the power of language resides in its organization as a huge network of interrelated choices' (2003:8). Accordingly, grammar and grammatical metalanguage are conceptualized as resources to assist students in learning how to shape meaning. This stands in stark contrast to traditional views of grammar with their emphasis on identification and labelling of grammatical features and their preoccupation with error eradication 
and notional rules (Marenbon 1994; Macdonald 1995). Instead a functional approach draws attention to the possibilities of language choice in shaping meanings and nuances.

Developing learners' understanding of how language shapes meaning is at the heart of our thinking about metalinguistic understanding in writing, and the role that dialogic talk plays in supporting metalinguistic thinking. Gombert (1992) distinguishes between declarative and procedural metalinguistic knowledge: declarative knowledge being the knowledge of and ability to state rules and principles, whilst procedural knowledge is the ability to put this knowledge into action (1992:191). Bialystok's distinction (1994) between analysis and control develops this further. She argues that analysis and control are key cognitive functions in language development. The process of analysis involves the transformation of everyday, informal knowledge about meanings into 'explicit representations that are organized around formal structures', in particular how meanings are signified (1994:159). Relevant to the argument in this paper, she notes that analysis is more difficult and complex for written language than for oral language because mental representations of meaning in writing involve 'such symbolic relations as the connection between letters and sounds' (1994:159). The process of control is the execution of selective attention, a 'processing choice about where attention should best be spent' (1994:160) for a given task. As control develops to a higher level, learners are able to make better use of their knowledge and understanding to fulfil language tasks.

In the context of writing and consistent with a Hallidayan theorization of language, declarative metalinguistic knowledge relates both to the knowledge of the grammatical system itself, and to how it shapes and creates meaning in written text, whilst procedural knowledge relates to the capacity to draw on and execute that knowledge in the process of writing. It is important to acknowledge at this point that learners can demonstrate declarative metalinguistic knowledge without the use of grammatical terminology, using their own everyday language. However, our primary interest in this paper is the role of the teacher's talk in scaffolding and enabling explicit grammatical metalinguistic understanding. This concern for the facilitating capacity of teachers' talk in the context of teaching writing draws on contemporary theories of talk as a socially constructed tool for meaning-making (Wells 1999; Mercer and Littleton 2007; Wegerif 2011). Specifically, it draws on Vygotsky's argument that moving from thought to written language requires 'deliberate semantics-deliberate structuring of the web of meaning' (Vygotsky 1986:182): the repetition of deliberate is salient here, as it signals the importance of explicitness and thus of metalinguistic understanding in writing development. Our own argument is that learners' capacity to think metalinguistically about writing and to enact that thinking in the composing of text is enabled through high-quality classroom talk. Vygotsky (1986) also maintained that talk is both a cultural tool that allows knowledge to be shared and developed within communities, and a psychological tool that structures the processes and content of individual thought. In other words, potentially, classroom talk can be the cultural tool which supports the construction of shared declarative metalinguistic knowledge and the psychological tool which supports writers' cognitive capacities to use that knowledge procedurally in the shaping of their own written texts.

One element of such classroom metalinguistic talk is metatalk. The origin of the concept of metatalk is usually ascribed to Swain $(1995 ; 1998)$, who identified three kinds of output in second language (L2) learning: noticing, hypothesis testing, and metalinguistic reflection, which she termed metatalk. Fundamentally, metatalk involves learning using language to reflect on language use. Swain 
describes it as 'a surfacing of language used in problem solving; that is, language used for cognitive purposes' (Swain 1998:69) and argues that giving learners' opportunities for metatalk is a purposeful method for supporting language learning. Swain also emphasises the importance of metatalk occurring 'in contexts where learners are engaged in meaning-making, that is, where the language being used and reflected upon through metatalk is serving a communicative function' (Swain 1998:69). Thus metatalk is more than recognising and understanding the form of language: it is a 'deeper level of attention' which supports learners' developing knowledge about the relationship 'between meaning, form and function' (Storch 2008:96). Roehr and Gutierrez (2013) argue that the value of metatalk lies in permitting 'the examination of the nature of ... the mental representations that learners resort to' (Roehr and Gutierrez 2013:150), signalling the place of metatalk in allowing teachers to see how learners are thinking about language.

In this way, metatalk is seen as a pedagogical tool, and several empirical studies have investigated the concept from different perspectives. Storch (2008) considered the nature of engagement of pairs working on a text reconstruction task focused on the kinds of tasks which generate metatalk, and concluded that elaborate engagement, characterised by paired deliberation and discussion supported language learning more effectively than limited engagement. Similarly, in a study with adult second language learners, Qi and Lapkin (2001) analysed think aloud protocols generated through a language comparison task and found two levels of 'noticing' - a superficial level which simply described the differences and a more substantive level, the metatalk, where learners verbalized their reasoning in accepting or rejecting changes in the text. They suggest that 'verbalization itself may be an effective strategy' (2001: 296) and Swain (1998) notes the value of teacher modelling of metatalk. Addressing writing specifically, Schaeffer-Lacroix (2016) investigated the learning impact of corpus-informed metatalk on verb particles, relevant to the writing task being undertaken, and concluded that the activities helped students to talk more precisely about language. Ishikawa (2015) investigated students' writing of metanotes, a form of written metatalk, to reflect on their language use as they worked on task, and found that the metanotes enabled learners to deepen understanding because they could revisit and consolidate on initial thoughts. The New Zealand Ministry of Education recommend the use of metatalk in bilingual Pasifika classrooms as a tool for helping learners clarify their choice of vocabulary or forms (NZ Ministry of Education: no date). Both Swain (2006) and Suzuki and Itagaki (2007) conclude from their studies that there is a positive cognitive effect of metatalk. These empirical studies, then, suggest that metatalk can have direct benefits for language learners as a pedagogical tool: activities which generate metatalk can foster language learning. Significant to this paper, metatalk is also important pedagogically in allowing teachers to understand what students are learning. Common to all the studies is the emphasis placed upon the verbalizing of metalinguistic knowledge and the level of thinking revealed through that verbalization.

However, this body of work on metatalk relates exclusively to second language learners who are simultaneously acquiring understanding of the language system of the target language and how to communicate meaningfully in that language. The study reported here extends the concept of metatalk to an L1 context and to talk about language choices in writing which are functionallyoriented (Halliday 2004), rather than form-oriented. Even in the L2 research, despite the emphasis on the learning value of metatalk, there is very little about how teachers can facilitate metatalk. In this respect, the facilitation of effective metatalk to develop learning about writing and language choices can usefully draw on thinking about dialogic pedagogies and dialogic space. Building on 
Vygotsky's (1986) view of talk as both a cultural tool for developing and sharing knowledge and a psychological tool which structures individual thinking, we have found Wegerif's metaphor of dialogic space a helpful way to consider pedagogical interactions through metatalk. Wegerif (2013:62) describes dialogic space as 'the space of possibilities that opens up in dialogue' and he argues that pedagogically we could helpfully 'talk about 'opening dialogic space', through interrupting an activity with a reflective question, for example or 'widening dialogic space' through bringing in new voices or 'deepening dialogic space' through reflection on assumptions' (Wegerif 2013:32). Writing, certainly in the current high-stakes assessment climate in England, is increasingly dominated by advocacy of formulaic structures and narrowed checklists of what a particular genre of writing should contain. But effective metatalk should enable developing writers not simply to replicate pre-determined linguistic structures or forms in their composition, but to understand the different ways in which linguistic choices can shape different meanings, and to make choices for themselves. It is also always a matter of exploration and interpretation, not a matter of fact. This involves critical reflection on written text, listening to the voices of others, and an open-mindedness about pre-existent assumptions, and is as important a characteristic of teacher talk as it is of learner talk. Alexander (2003:36) describes dialogic teaching as 'purposeful and productive dialogue where questions, answers, feedback (and feedforward) progressively build into coherent and expanding chains of enquiry and understanding'. Such a view of classroom talk represents a dialogic pedagogy frequently contrasted with monologic pedagogies which close down talk and control learning (Edwards and Mercer 1994; Wells 1999; Skidmore 2000). The data we present in this paper will illustrate how teachers' orchestration of metatalk supports learners' capacity to engage in metalinguistic discussion about writing, and the role of a dialogic pedagogy in securing high-quality writing talk.

\section{Methods}

This paper draws on data from a study in England involving a randomized controlled trial (RCT) with a complementary qualitative dataset. Drawing on the outcomes of previous research studies by the research team (Myhill et al 2012; Jones et al 2013a; Myhill et al 2013), teachers were mentored in a pedagogical approach involving explicit attention to grammatical choices which set out to develop students' metalinguistic understanding of writing and writerly decision-making. One aspect of this approach was the advocacy of high-level metatalk about textual choices, intended to support young writers in becoming autonomous and independent in managing their composing decisions. Whilst the RCT element of the study set out to examine the efficacy of the intervention, the qualitative study, reported here, gathered data to investigate the teachers' management of high-quality metatalk and the nature of that metatalk.

\section{The sample}

The sample for the study involved 54 state primary schools from regions across England, representing demographic diversity and yielding a total sample size was 779 students. In each school, two classes of students aged 10-11 were randomly allocated to either the intervention or the comparison group. The sample also included the class teachers of each of these classes $(n=108)$.

\section{The Intervention}

The intervention involved two related strands. Firstly, a set of instructional materials were designed, focusing on the writing of fictional narrative, which embedded grammatical focuses relevant to fictional narrative at appropriate points in the instructional sequence. Secondly, three professional 
development sessions were held which introduced teachers to the pedagogical principles underpinning the instructional materials. These sessions were followed by an in-school coaching visit prior to implementation of the intervention.

The teaching materials used in the intervention took Arthurian legend as its theme, using Michael Morpurgo's book, Arthur, High King of Britain, and the BBC TV series, Merlin, as stimulus material. The materials drew attention to grammatical choices which supported writing fictional narrative: for example, how noun phrases can create visual descriptions of characters; how adjectives in a postmodified position draw attention to the description they evoke; how both noun phrases and verb choices can suggest or imply character without needing to state it directly; and how subject-verb inversions can create suspense or anticipation in a key plot moment. (For more detail about the content of the intervention see Jones et al 2013b).

\section{Procedures}

In addition to statistical analysis of outcome measures, lesson observations were undertaken to investigate the nature of the metalinguistic discussion. One lesson, randomly selected, was observed in each intervention school, bar one, due to staff illness, giving a dataset of 53 lesson observations. A semi-structured observation schedule was used which focused upon how the teacher's input linked grammar and writing and fostered high-quality talk, and upon student responses. Each lesson was also audio-recorded and later transcribed to provide discourse data available for analysis. Subsequently the observation record was combined with transcribed data to create a final record of each lesson. It is this data which informs this article.

\section{Data analysis}

The data were analysed inductively, following the constant comparison method, with an initial stage of open coding, followed by axial coding which clustered the data into thematic groups. The open coding was guided by the research questions, focusing on teacher management of high quality talk and the nature of that talk and was informed by theoretical understandings of dialogic talk and of metalinguistic understanding. There were four coders and a systematic, iterative process of analysis was adopted to achieve consistency. Initially, each coder open-coded independently the same transcript, followed by team discussion of the codes which had evolved and an agreement on initial codes. The coders then independently coded four different transcripts and met again to compare and refine code labelling. At this stage, the coding discussion was principally focused upon agreeing the naming of codes and their definitions. Subsequently coders coded five more transcripts each, prior to another team meeting rechecking, merging, splitting, and re-labelling codes, as appropriate. For example, our initial coding had created two codes - Skilful Management of Discussion and Less Skilful Management of Discussion. This was refined so that one top level code, Discussion, was created with 6 sub-codes which more subtly represented the data. At the same time, a further layer of clarification of code labelling and definitions was undertaken, leading to, for example, the merging of two codes which were proving to overlap, Non-Linguistic Connection and Semantic Connection into one code, Non-Grammatical Connection. At this stage, emerging axial codes were evident and so existing codes were re-organised under five axial codes:

$\square$ Connections between Grammar and Writing;

a Discussion;

- Subject Knowledge;

- Student Understanding; 
Evidence in Writing.

Coders then completed the coding of all the transcripts, and a final meeting checked and agreed all the codes, determining the appropriacy of the code label, its definition, and the match of data segments attributed to that code to its definition.

Findings:

This article draws on the data coded under the Connections between Grammar and Writing axial code, as this code related most strongly to metalinguistic understanding and the making of connections between grammatical choices and their use in written text. Seven sub-codes related to this axial code were identified in the coding process as outlined in Table 1.

\begin{tabular}{|l|l|}
\hline CODE & DEFINITION \\
\hline $\begin{array}{l}\text { Explicit connection made } \\
\text { between grammar and } \\
\text { effect }\end{array}$ & $\begin{array}{l}\text { Connection made between grammatical term or } \\
\text { construction and its effect in writing }\end{array}$ \\
\hline Writers' choices & Attention to the choices writers have made/could make \\
\hline Effect on the reader & Attention to reader perspectives or reader responses \\
\hline Non-grammatical connection & $\begin{array}{l}\text { Connection made between choice and effect without } \\
\text { use of grammatical terminology }\end{array}$ \\
\hline Word choice and vocabulary & Focus on word or vocabulary choices \\
\hline Missed connection & $\begin{array}{l}\text { Missed opportunity to make a connection between } \\
\text { choice and effect in writing }\end{array}$ \\
\hline Deploying grammar & $\begin{array}{l}\text { Writers encouraged to put particular grammar features } \\
\text { in their writing, but no meaningful connections made }\end{array}$ \\
\hline
\end{tabular}

Table 1: showing the codes and definitions within the Connections between Grammar and Writing theme

\section{Modelling metatalk through signalling explicit connections}

The code named Explicit connection made between grammar and effect represented those occurrences in the teaching where the teacher's talk made visible to learners how a particular grammatical choice related to a particular effect in writing. In this way, they modelled how to verbalise the ways in which language choices shape meaning. The teaching materials themselves clearly established a grammar-meaning relationship and encouraged metatalk which made these connections. However, the teachers used these materials in different ways and their talk, as in most teaching, was largely improvised in the moment.

Where teachers effectively modelled metatalk about grammar-writing relationships, they did so at different points in pedagogical sequences. Sometimes, the teacher made the link at the point of setting a writing task, foregrounding the learning purpose of the task, as in the two examples below, both focussing on how noun phrase choices can support characterisation:

Think about your noun and adjective choice - a physical description that gives an impression of what the character is like. 
You're going to write a description of your character to help the reader visualise exactly what you're visualising yourself. Your word choices are really important; I want you to focus on using nouns and adjectives carefully. Make sure every word you use counts.

At other times, teachers articulated very clearly the precise grammar-meaning relationship that was the focus of the lesson, drawing on Morpurgo's writing as the model. Here the teachers picked up on the pedagogical intention of the teaching materials but elaborated or underlined it in their own words:

The verbs that were showing and implying what the character is like by what they do.

You can build a noun phrase by adding more description after the noun, which is what this description is doing, it's really trying to paint a picture in our head of what this man looks like ... how horrible his eyes are.

We often put the adjective in front of the noun, but where is it here? It's afterwards... giving it detail. .... where the description comes after the noun; what a rich description of the hair, colour of honey, gold washed in milk, painting that picture in our mind.

Less frequently, the teachers noticed particular choices made in children's own writing and drew attention to it, verbalising how the child's writing had effectively shaped meaning through a particular choice. In the example below, the teacher responds to the child's writing by verbalising her own response as a reader to the delayed subject:

That I love - you've put the subject much further on, and I was left waiting for what you were going to say.

Sometimes the modelling of metatalk was through a questioning sequence, where the teacher's questioning set out to support children's metalinguistic understanding of authorial choices, and concluded the sequence with a summary explanation:

Teacher: $\quad$ A giant of a man rode in on a towering warhorse? Pawed the ground? Tossing its fine head. Froze the courage in a man's veins. We've got verbs that tell us...?

Student: $\quad$ His actions are firm and decisive ... a confident man

Student: $\quad$ The horse seems aggressive, tossing and snorting, and ready to fight.

Teacher: The way that Michael Morpurgo is choosing the language has shown us that the horse is angry, he didn't write "the horse is angry".

Teacher: $\quad$ Why would you use a short sentence in your King Arthur story? What would that do? What effect would it have on me?

Student: $\quad$ Using a short sentence draws attention

Student: It creates tension

Teacher: $\quad$ Yes, to focus attention on an object, or a person, on a key event.

These examples of teachers modelling through metatalk frame students' capacity to think metalinguistically about writing. Although the teachers are addressing particular learning objectives 
related to grammatical choices in narrative fiction, their talk is not directed towards right answers, or to formulaic prescriptions of good writing. Rather, through the modelled talk they open up students' thinking about the possibilities available to them as writers, and potentially develop their awareness of how the choices they make can achieve particular authorial goals.

\section{Metatalk which foregrounds Writers' Choices and Reader Awareness}

The codes designated as Writers' Choices and Effect on the Reader are parallel codes, reflecting the symbiotic relationship between reading and writing. Through examining authentic texts and how they are crafted and shaped, teachers are drawing attention to the writer behind the text, and in the context of children's own writing, they are developing young writers' awareness of how their own authorial choices might shape a reader's response. Teachers' talk represented in these two codes, therefore, was not simply about textual possibilities but about the inter-relationships between readers, writers and texts.

One cluster of talk in this category represents interactions where teachers invited children to consider the author's perspective and to think about why a writer may have made a particular choice. Frequently, the interactions here asked children to speculate about the author's intentions or to become aware of the potential effect of an authorial decision:

Teacher: What is the subject of the sentence?

Student: The sword

Teacher: Why do you think he's chosen to do it this way round? Why has he left the shining sword - the subject - until later in the sentence?

This emphasis upon a writer's intentions was sometimes introduced by the teacher stepping into the role of a writer, using shared writing as a way to foreground the writer's decision-making: What can I do to build the tension within a sentence, as a writer? In another episode, a teacher shares her own writing. She tells the class - This isn't our famous author now, this is me, Miss Shepherd, in the classroom. Ok. I wrote it when you wrote yours yesterday. She then invites them to discuss her writing, and when one student notes her 'choice of vocabulary', she shows her own thinking as a writer, reflecting on and speculating about alternatives:

Though I have to say when I was reading back through it this morning - 'As I gazed towards the entrance of the maze it was deadly quiet' - I wondered if I wanted to go for 'eerily quiet' instead. I wondered if that would give more of a sort of mystic vibe to it?

At other times, teachers foregrounded the children's status as writers, asking them to consider and justify their own choices as writers, or reminding them of their rights as a writer to make choices:

As a writer, you can make that decision, can't you, as to which one sounds the best. It doesn't happen by accident, writers make that choice, and you have that choice: if you know that you can put your adjectives before your noun or after.

Mirroring this emphasis on heightening awareness of writers' choices and authorial attention was the teacher talk which highlighted how different grammatical choices are linked to an effect on the 
reader. Many of the examples in this code were reminders before children started writing which alerted them to think about both the reader's needs and how the writing might meet those needs:

Imagine, as a writer, that you're introducing your character for the first time in a story. This is the first time your reader is going to encounter your character. You're going to write a description of your character to help the reader visualise exactly what you're visualising yourself.

Teachers sometimes took the opportunity to open up thinking about the reader in responding to students' own writing, sometimes by verbalising the impact of a language choice made by the student, or by inviting the student to think about different possibilities and how they might alter how a reader responds to the writing:

So you've delayed your subject: you leave the reader waiting, but hooked, to see what is the character.

Let's think about that section of your sentence, you've got a good noun phrase there, lips as red as blood. Could we change that into a different order? It's not going to change the meaning but it is going to change how the reader might feel about the character if we talk about her in a different way.

In the extract below, the teacher's questioning pushes students to articulate more clearly the effect of a subject verb inversion on the reader. The first student's response to the teacher's question is rather generalised and unspecific, so the teacher develops the metalinguistic thinking with a further question introducing the reader perspective. This time the student's response is more specific but the teacher continues the interaction to elicit an explanation of what language choice accounts for this effect on the reader:

Teacher: Why is that such a good sentence?

Student: They've described it well.

Teacher: Yes he has - but from the reader's point of view, what's just happened?

Student: He's made the reader wait.

Teacher: Good, but how has he done that, what has he done?

Student: He put 'the ring of fine gold' at the end. Not until the end of the sentence do we find out what it is.

\section{Metatalk about Word Choice and Vocabulary}

Teacher talk coded in this category represented a very close focus on individual word choices, sometimes directly linked to grammar such as nouns and adjectives, and sometimes simply considering 'words'. In the example below, the teacher picks up on a student's comment about the colour of Morgana's dress, and twice invites the student to elaborate on the response, until the student verbalises more explicitly the connection she has established between the choice of colour and characterisation. She then opens the discussion to others in the class for comment and elicits a connection between redness and blood. This snippet of metatalk triggers two further unsolicited interactions around word choice, suggesting that the teacher's management of talk here has both enabled explicit articulation of links between word choices and meanings but also that she has created space for other students to contribute their own ideas spontaneously: 
Student: And she's wearing a gown of wine-red.

Teacher: OK. Talk about that a bit more.

Student: She wouldn't wear a white dress.

Teacher: Why?

Student: Because if you was not evil, you would like wear yellow.

Teacher: Anyone got something else to comment on Anna's wine-red colour? Ahmed?

Student: It's like blood.

Teacher: Like blood. So think carefully when it comes to yours, think about the colours of what your writing is using.

Teacher: Asher?

Student: It says her long fingers 'extended'...

Teacher: 'Her long fingers extended': what does that make you imagine?

Student: [unclear]

Teacher: Yes, evil maybe: imagine those long fingers in your mind.

Student: When it says 'and the voice grew stronger and more insistent' and I was thinking a normal person wouldn't have her voice really deep.

However, examples such as the one above which probe the connotations and impacts of particular word choices in the context of the writing being generated were much fewer than examples where the focus seemed to be words in themselves, rather than the effect of the choice of those words. Typically, this talk appeared to value vocabulary as an end in itself, divorced from a contextual application, with no connections made between word choices and writer intention or imagined reader impact. Such interactions frequently closed down a discussion, rather than extended, and implied a right answer or value judgement, as in the example below where the verb choice 'enchants' is endorsed as a 'fantastic' choice and the interaction sequence ended:

Teacher: What other verbs can you use?

Student: He talks

Teacher: Yes he does talk, he's very wise with his words, but what other verbs could you use?

Student: He 'breathes fire'.

Teacher: He 'breathes fire'. Is that a verb? What is the verb?

Student: 'breathes'

Teacher: Yes 'breathes' - It glows, it illuminates up - that's your verb.

Student: 'Enchants'

Teacher: He 'enchants' the sword. Fantastic.

In another example, in a peer discussion about one student's writing, a peer points out too much repetition of the word 'big' which triggers an extended interaction sequence where students suggest alternatives, echoed by the teacher. This becomes an exercise in synonym finding with no purpose other than to replace 'big': there is no discussion of the different connotations of the suggested words and no link to purpose in writing or intended effect. Indeed the purpose seems to be to ensure they can 'level up' their writing, an expression probably only familiar in the English context where children's writing was nationally assessed in levels and teaching supported them in achieving higher levels: 


\author{
Student: She's got too many 'bigs' \\ Teacher: Overuse of the word 'big'. Who can think of different words we could have \\ instead of 'big'? \\ Student: Enormous. \\ Teacher: Enormous. \\ Student: Gigantic. \\ Teacher: Gigantic. \\ Student: Massive. \\ Teacher: Massive. \\ Student: Colossal. \\ Teacher: Colossal. \\ Student: Huge. \\ Teacher: Huge. \\ Student: Grand. \\ Teacher: Grand. \\ Student: Humungous. \\ Teacher: Humungous. \\ Student: Vast. \\ Teacher: Vast. \\ Student: Large. \\ Teacher: Large. \\ Teacher: So, whoever's writing that was, I hope they've now got a few ideas for how \\ they can level up.
}

The talk coded in this category, then, represents both effective metatalk about word choice and implications of those choices, and more pedestrian talk which generated little thinking about writerly choices. To an extent, it may be that talking about vocabulary is a comfort zone for teachers in the English curriculum context. They are often more comfortable talking about words than grammar, and it resonates with current standard pedagogic discourses of primary classrooms around 'wow words' or 'powerful words', endorsed by commercial materials.

\title{
Metatalk which makes a non-grammatical connection
}

The teacher talk coded in the Non-grammatical Connection category encompassed interactions or teacher comments which were focused on meanings and how meanings were made without use of grammatical terminology. The teachers were initiating or developing talk about writing but with less precision, sometimes using the term 'words' rather than the precise grammatical terminology. Sometimes, such comments were relevant to the context but rather generalised and advisory, not pinning down for learners how they might accomplish this:

Teacher: Yeah, to look at what works, what doesn't work, what works better, improve it with a purpose, not just look for another word which means the same thing. And we've been focusing on appropriate language choices. How to make it more powerful, more vivid, more clear.

In some cases, the teacher modelled how to improve a piece of writing, or discussed one aspect of the writing, but did not explain clearly why the changes represented an improvement or what the issues were that she was raising. In the example below, it is hard to determine what writerly decisions are the focus, and it is noticeable that the talk is monologic, with the teacher answering her own questions and closing down possible discussion:

Teacher: Ok I'll read it better then. 'Out of the darkness came a dark haired and beautiful lady, wearing a dark cloak. She stood there over the knight and casket.' I've changed it, Tim.

Student: [inaudible] 
Teacher: She had dark hair - I've put all of those words in there? Do I need all those words? No. Have they have got any power whatsoever? No? No they haven't.

Other examples included interactions where the teachers established an appropriate focus on writing and what is required in writing but missed an opportunity to think about language choices, focussing more strongly on ideas and content, than on how to shape writing and make linguistic choices. Significantly, many of these incidences were teaching points addressed in the teaching materials where the link between a grammatical choice and how it shapes meaning was explicit, and scaffolded for the teachers. However, teachers drew out the narrative learning point, but did not use the explicit grammatical link to illustrate how these goals could be achieved:

Teacher: 'fingers extended, eyes wide and intense'. That's the kind of physical description we want from you. The physical description that actually allows you to see that character in your head. You can see what that character is doing.

Teacher: Try not to tell me too much about the story... I want to be able to imagine your character and maybe tell if they're a good or bad character.

Teacher: I want you to look for images ... look at Nimue, we're going to look at Arthur, we're going to look at Gaius, and we're going to be looking at Merlin and Guinevere. I want you to look at images which show or suggest what the character is like from what they do.

In general, interactions in this category tended towards semantic talk, rather than metalinguistic talk, with a focus on the semantic or literal meaning of choices, not how meaning is constructed. Of course, not all valuable talk in a writing lesson needs to be grammatical, but what is relevant here is the apparent avoidance of grammatical terminology where the materials offered it, perhaps reflecting some teachers' beliefs about grammar or a lack of grammatical subject knowledge confidence.

\section{Metatalk which initiates without development}

The code Missed Connection had some similarities to the previous code (non-grammatical connection) but represented teacher talk where grammatical terminology was used at a relevant moment in a pedagogical sequence but students' thinking was not developed further. Here teachers were initiating potentially rich talk about writing but ending the interaction without developing it. Some of these interactions show teachers drawing out success in students' work and holding it up for praise, establishing a positive atmosphere in the classroom. From a learning perspective, the children know what they have done well, but they do not know why it is good, as this is the missing element in the teacher talk:

Student: That is Excalibur

Teacher: That's the one I was thinking of. ... What is Excalibur... impact!

Teacher: Some amazing post-modification going on there -impressive! 
Student: Rusty old casket

Teacher: Fantastic adjectives

Teacher: Yes, so which way has she post-modified that one - 'washed in lava'

Student: A non-finite clause

Teacher: It's just those little bits of detail that makes your writing so delicious, and so exciting.

Sometimes these undeveloped or imprecise initiations of metatalk may reflect teachers trying very hard to adopt a kind of classroom talk which is not very familiar to them, and which is not yet fully their own. In the example below, the teacher is looking at how moving adjectives into a postmodified position (flipping it round) can alter the emphasis on the adjectives. She does not use the grammatical terminology which might have helped with the precision of the explanation, and she struggles to verbalise the effect:

Teacher: I want to try flipping it round and that's what we're going to be doing. Look at the board. Here are some other things that came out of our description yesterday. It tries to get this visual thing into your brains from the paper - not just basic, it's richer - 'Her fingers, long, white and dancing.

Focusing on the same idea of the possibilities afforded by post-modifying adjectives, another teacher uses the grammatical terminology to initiate a discussion about adjectival position, but again there is no development which supports young writers in understanding why this move might be a valid writerly choice. Instead it seems to be presented more as a literal choice between putting adjectives before the noun or after the noun:

Teacher: Can anyone find an example where the phrase, the adjective, comes after the noun?

Student: I think when you say the lady who is beautiful or the lady is beautiful

Teacher: Any others?

Teacher: We've got 'the voice', how did we describe the voice?

Student: Louder, stronger, intense

Teacher: Great, we've got 'the voice', the noun, and then the description following it. So when you're doing your writing, consider where you put those adjectives, not always before the noun but describing it afterwards as well.

\section{Metatalk which encourages writers to 'deploy' grammar}

The final code Deploying Grammar refers to talk statements or interactions in which teachers steered or cued students towards 'putting in' certain grammar features to improve their writing, but with no link made between that deployment, writer choices and language effects. Of all the metatalk discussed in this article, this is the least valuable, suggesting that effective writing is more about displaying what you can 'get in' to your writing, rather than developing deepening understanding of the repertoire of choices available. Such metatalk rarely open up student talk: rather it tended to close it down and invite no further engagement:

Teacher: Don't forget, can you get a short sentence in there? 
Teacher: Can you put adjectives after the noun; can you put a prepositional phrase?

Teacher: And think about how you could add nouns, I'd really like to see some noun phrases with post-modification, adjectives after to describe. You might have a go at adding some -ed verbs or some -ing verbs after the noun as well.

Teacher: Can we add some -ing or -ed verbs into our sentence, this is thinking about what the person is doing.

Student: The cloak resting on his tight mighty shoulders

Teacher: Yes that's a non-finite clause - that's like uber posh!

Some of these examples may be a consequence of the emphasis on grammar in the teaching materials and teachers' knowledge that grammar was a key focus in the intervention. This may have led to an over-emphasis on the grammar, without full professional understanding of the principles of the intervention and its goal to link grammar choices and meaning. However, it is also likely to reflect current pedagogical practice in the teaching of writing in primary schools in England. In a high-stakes assessment regime with high levels of accountability on teachers to raise standards, the teaching of writing has become very test-driven. The use of toolkits and checklists for writing are commonplace in classrooms, and these do suggest that writing is about remembering to 'deploy' certain features. There are a plethora of commercial materials which support this, such as Ros Wilson's Big Writing, which often, unwittingly, encourage teachers to teach writing rather formulaically. And at the time of writing this article, the English government have issued clarification on what constitutes an 'exclamatory sentence' because in order to achieve the 'expected standard' nationally 'must use sentences with different forms in their writing' (UK Government Standards and Testing Agency 2016:3). Currently, as a consequence, teachers are advising students that they need to use some exclamatory sentences in their writing, reinforcing this notion of writing being a process of deploying particular features. In terms of metatalk, however, this kind of teacher talk tends towards rather meaningless interactions, which do not foster deepening metalinguistic understanding about writing, but compliance with pre-determined norms.

\section{Discussion}

In the framing article for this Special Issue, dialogic space is defined as one 'where multiple meanings are explored and developed' (Jesson et al: this issue) and in the context of the study reported here, our interest is in how teachers create these dialogic spaces which enable and facilitate the exploration of the multiplicity of meanings available to writers in making language choices and support them in thinking metalinguistically about written text. Whilst $L 2$ research on metatalk has signalled its learning benefit (eg Ishakawa 2015; Schaeffer-Lacroix 2016), the data generated by this study offers a detailed and nuanced understanding of the nature of such metatalk in L1 classrooms, and of the notion of dialogic space in this context.

The analysis shows teachers involved in this study actively engaged in trying to use metatalk productively. Table 1 illustrates that a high proportion of the teacher sample were modelling metatalk through signalling explicit connections between grammar and writing, and foregrounding thinking around writer choices and reader awareness. This kind of metatalk most strongly 
represents 'the space of possibilities that opens up in dialogue' (Wegerif 2013:32) and is most closely oriented towards developing metalinguistic understanding about writing. It sets out to make visible to learners the linguistic choices they can make in writing and encourages learners to see themselves as writers with access to a repertoire of choices, and to consider their potential readers. The interactions do not steer towards pre-determined right answers but towards consideration of authorial possibilities and explicit understanding of how grammatical choices are part of the 'huge network of interrelated choices' (Halliday 2003:8) which enable meaning creation in written text.

The teacher talk which was concerned with word choice and vocabulary, or which made nongrammatical connections, or initiated a talk sequence but did not develop it was arguably less successful in creating dialogic space. Although, in general, the metatalk in these interactions did not steer towards 'right' answers, they represent interactions where opportunities were missed for making connections between language choices and authorial intentions or possibilities. They may be important, however, as interactions which offer clear potential for opening up dialogic space for developing metalinguistic talk about writing. The opportunity for exploring multiple meanings as a community of writers was evident, but not exploited: what was missing was the questioning and feedback which 'build into coherent and expanding chains of enquiry and understanding' (Alexander 2003:36). It is possible that the metatalk here was constrained because these teachers were on a professional learning curve themselves, mastering a new pedagogical approach.

In contrast, the metatalk which encouraged writers to 'deploy' grammar represent interactions which did not open up dialogic space for developing metalinguistic talk about writing. It did not enable learners to develop understanding of the linguistic choices they could make in writing, and tended to close down responses, strongly geared towards right answers, and to a norms-driven, formulaic view of writing choices. This kind of metatalk is a more monologic discourse, which is 'authoritative', and which is 'not open to question or alternative perspectives' (Wells 2007:256), thus narrowing the space for metalinguistic thinking about writing.

It is axiomatic that the teacher's role in orchestrating classroom talk is a crucial one and one, indeed, which has been a sustained focus for pedagogical research (Cazden 1988; Edwards and Westgate 1994; Galton et al 1999; Alexander 2008). However, what is salient in the context of this study is the role that teachers play in the creation of dialogic spaces for the exploration of semiotic mediation in writing, and how they initiate and develop metalinguistic talk about writing. There is a tendency in the broader field of research into dialogic talk to contrast and counterpoint monologic and dialogic discourses as binary opposites. Whilst it is possible to describe the interaction patterns revealed in this study as a contrast between high-quality metatalk, characterized by an open dialogic discourse, and less effective metatalk, characterized by more controlled, monologic closed discourse around writing, such dichotomies may be unhelpful, and miss some of the subtleties of what is happening. Firstly, they play into a value-laden view of the dialogic as inherently 'better' talk, 'where direct instruction or unidirectional transmission of knowledge is often pitted against open-ended, studentcentred inquiry' (O'Connor and Michaels 2007:276). However, Wells (2007) argues that there is a need for both the monologic and the dialogic in classroom discourse, and in metatalk about writerly decision-making, there is sometimes a need for the teacher to be authoritative, for example, around the identification of a particular grammatical construction. Similarly, in the context of Science classrooms, Scott, Mortimore and Aguiar (2006) position 'transitions between dialogic and 
authoritative interactions as being fundamental to supporting meaningful learning of disciplinary knowledge as different teaching purposes are addressed' (2006:623).

More significantly, though, binary oppositions can over-simplify the complexity of leading metatalk. One strand of analysis of the data in this study indicated that individual teachers were rarely always dialogic, or always monologic, and were more likely to exhibit both characteristics across the discourse of one lesson (Myhill et al 2016). Lefstein (2010) has cautioned against such binary oppositions and idealized models of talk, proposing instead 'a situated model of dialogue, sensitive to the tensions inherent in dialogic interaction and appropriate to contemporary school contexts' (2010:170). The teachers in this study were working within contextual constraints, and classroom talk is heavily improvised in the pedagogical moment, thus perhaps particularly amenable to the influence of other factors. The influence of high-stakes national assessments, noted earlier in this article, constitutes a powerful force which drives writing instruction towards the perceived requirements of an assessment regime with apparently prescriptive expectations. At the same time, specific to this intervention, teachers' grammatical subject knowledge in England is not strong (Myhill et al 2013) which, despite the support of the teaching materials, may have influenced their confidence in handling this kind of metalinguistic discussion and precipitated narrowing of discussion. Greater grammatical assurance might have supported more open-ended discourse, where teachers were confident in responding to 'everyday ideas in attempting to move along the students' ways of talking and thinking' (Scott, Mortimore and Aguiar 2006). Moreover, the nature of talk promoted in the intervention is a new and unfamiliar kind of language talk for most teachers, and the spectrum of interactions may reflect teachers' own professional learning about how to lead this kind of metatalk.

In conclusion, then, teachers themselves may not be monologic or dialogic, and metatalk may be positioned at different points of a continuum from monologic to dialogic, sometimes because an authoritative initiation or response is needed, sometimes becomes other constraints acts as inhibitors. If effective metatalk involves 'a surfacing of language used in problem solving' (Doughty and Williams 1998:69), and recognising that metalinguistic understanding is a more complex activity in writing because of its symbolic nature (Bialystok 1994), generating classroom talk which enables analysis of how grammatical choices create meanings in written text and which enables writer control through selective attention to their own decision-making makes high pedagogical demands on teachers. This paper has outlined how teachers' management of discussion about metalinguistic choices in writing frames students' capacity to think metalinguistically about their writing, and has argued that dialogic spaces for metatalk about writing are created by the teachers' adoption of more open dialogic discourse roles. As a relatively new area of inquiry, however, further research is needed which explores in detail how dialogic spaces can be opened, widened or deepened (Wegerif 2013) to enhance metalinguistic thinking about writing and writerly decision-making, and which takes account of teachers' own professional and pedagogical positioning. 


\section{References:}

Alexander, R. 2008. Towards Dialogic Teaching: Rethinking Classroom Talk. 4th ed. York: Dialogos.

Alexander, R.J. (2002) Culture and Pedagogy: International Comparisons in Primary Education. London: Blackwell

Allford, D. and Pachler, N. (2007) Language, Autonomy and the New Learning Environments. Bern: Peter Lang.

Barrs, M., and V. Cork. (2001). The Reader in the Writer: The Influence of Literature upon Writing at KS2. London: Centre for Literacy in Primary Education.

Bialystok, E. (1994). Analysis and Control in the Development of Second Language Proficiency. Studies in Second Language Acquisition, 16, pp 157-168.

Cazden, C. (1988). Classroom discourse: The language of teaching and learning. Portsmouth, NH: Heinemann.

Doughty, C and Williams, J. (1998) Focus on Form in Classroom Second Language Acquisition Cambridge: Cambridge University Press.

Edwards, D. and Mercer, N. (1987) Common Knowledge. London: Methuen

Gombert, E. J. (1992). Metalinguistic Development. Hemel Hempstead: Harvester Wheatsheaf

Halliday M.A.K. (2003) Introduction: On the 'architecture' of human language. In: Webster J (ed.) On language and linguistics: Volume 3 in the collected works of MAK Halliday. London and New York: Continuum, pp 1-29.

Halliday M.A.K. (1994) An introduction to functional grammar. London: Hodder.

Halliday, M. A. K. (2004). “Three Aspects of Children's Language Development: Learning Language, Learning through Language, Learning about Language". In The Language of Early Childhood, edited by J. J. Webster, New York: Continuum. pp308-326

Ishikawa, M. (2015) Metanotes (written languaging) in a translation task: do L2 proficiency and task outcome matter? Innovation in Language Learning \& Teaching. 9 (2) 115-129

Jones, S.M. Myhill, D.A. and Bailey, T.C. (2013a) Grammar for Writing? An investigation into the effect of Contextualised Grammar Teaching on Student Writing. Reading and Writing 26 (8) 12411263

Jones, S. Myhill, D.A. Watson, A and Lines, H.E. (2013b) Playful Explicitness with Grammar: A Pedagogy for Writing Literacy 47 (2) 103-111

Kellogg, Ronald. T (1994) The Psychology of Writing Oxford: Oxford University Press

Lefstein, A. (2010) More helpful as problem than solution: some implications of situating dialogue in classrooms. In Littleton, K. \& C. Howe (Eds.), Educational Dialogues: Understanding and Promoting Productive Interaction. London: Routledge. pp170-191

MacDonald, Heather (1995) 'Why Johnny can't write - teaching grammar and logic to college students' The Public Interest, 22 June.

Marenbon, J. (1987) English Our English. London: Centre for Policy Studies.

Mercer, N., and Littleton, K. (2007). Dialogue and the Development of Children's Thinking: A Sociocultural Approach. Abingdon: Routledge.

Myhill, D.A. Jones, S and Watson, A. (2013) Grammar Matters: How Teachers' Grammatical Subject Knowledge Impacts on the Teaching of Writing Teaching and Teacher Education 36:77-91 
Myhill, D.A. (2011). 'The Ordeal of Deliberate Choice': Metalinguistic Development in Secondary Writers in Berninger, V (Ed) Past, present, and future contributions of cognitive writing research to cognitive psychology. New York: Psychology Press/Taylor Francis Group. pp247-274

Myhill, D.A. Jones, S.M., Lines, H. \& Watson A. (2012). Re-Thinking Grammar: the Impact of Embedded Grammar Teaching on Students' Writing and Students' Metalinguistic Understanding. Research Papers in Education, 27 (2), 1-28.

Myhill, D.A., Jones, S.M. and Wilson, A.C. (2016) Writing Conversations: Fostering Metalinguistic Discussion about Writing. Research Papers in Education 31(1):23-44

New Zealand Ministry of Education (no date) LEAP: What do students learn from interaction? http://leap.tki.org.nz/What-do-students-learn-from-interaction Accessed 26.03.16

O'Connor, C. and Michaels, S. (2007) When is Dialogue 'Dialogic'? Human Development 50 (5) 275-285

Qi, D.S. and Lapkin, S. (2001). Exploring the role of noticing in a three-stage second language writing task. Journal of second language writing, 10, 277-303.

Roehr, R. and Ganem-Gutierrez, G. (2013) The Metalinguistic Dimension in Instructed Second Language Learning A\&C Black,

Schaeffer-Lacroix, Eva (2016) Talking about German verb particles identified in concordance lines from spontaneous to expert-like metatalk. Language Awareness. 25 (1/2) 127143

Scott, P. H., Mortimer, E. F., \& Aguiar, O. (2006). The tension between authoritative and dialogic discourse: A fundamental characteristic of meaning making interactions in high-school science lessons. Science Education, 90 (4), 603-631.

Skidmore, D. (2000) From pedagogical dialogue to dialogic pedagogy. Language and Education, 14 (4) 283-296

Storch, N. (2008) Metatalk in a Pair Work Activity: Level of Engagement and Implications for Language Development, Language Awareness, 17:2, 95-114

Suzuki, W., \& Itagaki, N. (2007). Learner metalinguistic reflections following output-oriented and reflective activities. Language Awareness, 16 (2), 131-146.

Swain, M. (1995). Three functions of output in second language learning. In G. Cook \& B. Seidlhofer (Eds.), Principle and practice in applied linguistics: Studies in honour of H.G. Widdowson (125-144). Oxford: Oxford University Press.

Swain, M. (1998). Focus on form through conscious reflection. In C. Doughty \& J. Williams (Eds.), Focus on form in classroom second language acquisition (64-81). New York: Cambridge University Press.

Swain, M. (2006). Languaging, agency and collaboration in advanced second language learning. In H.Byrnes (Ed.), Advanced language learning: The contributions of Halliday and Vygotsky (pp. 95-108). London: Continuum.

UK Government Standards and Testing Agency (2016) Clarification: key stage 1 and 2 teacher assessment and moderation guidance. London: Standards and Testing Agency

Vygotsky, L.S (1986). Thought and language (A. Kozoulin, Ed. and Trans.). Cambridge, MA: MIT Press.

Wegerif , R.B. (2011). Towards a dialogic theory of how children learn to think. Thinking Skills and Creativity, 6(3), 179-190

Wegerif, R.B. (2013). Dialogic: Education for the Internet age. London ; New York, NY: Routledge. 
Wells, G. (1999). Dialogic inquiry: Towards a sociocultural practice and theory of education. Cambridge: Cambridge University Press.

Wells, G. (2007) Semiotic mediation, dialogue, and the construction of knowledge Human Development 50 (5)244-274.

Wilson, Ros. (no date) Big Writing https://global.oup.com/education/content/primary/series/bigwriting/?region=uk Accessed 17.03.16 